\title{
Use of topsoil for restoration of a degraded pasture area
}

\author{
Luise Andrade Amaral ${ }^{(1)}$, Israel Marinho Pereira ${ }^{(1)}$, Michele Aparecida Pereira da Silva ${ }^{(1)}$, Marcio \\ Leles Romarco de Oliveira(1), Evandro Luiz Mendonça Machado(1) and Marcelo Luiz de Laia(1)
}

\begin{abstract}
(1)Universidade Federal dos Vales do Jequitinhonha e Mucuri (UFVJM), Departamento de Engenharia Florestal, Rodovia MGT 367, km 583, no 5000, Alto da Jacuba, CEP 39100-000 Diamantina, MG, Brazil. E-mail: andrade.luise@hotmail.com, imarinhopereira@gmail.com, michelesilva04@yahoo.com.br, marcioromarco@gmail.com, machadoelm@gmail.com, marcelolaia@gmail.com
\end{abstract}

\begin{abstract}
The objective of this work was to evaluate the influence of topsoil thickness, shading and origin when performing environmental restoration in a degraded pasture area. The experiment was conducted in a randomized block design with a factorial $(3 \times 2 \times 2)+2$ layout. Treatments consisted of combinations of topsoil origins (forest at early or middle regeneration stages), topsoil thicknesses $(10,20$, or 30 -cm superficial soil layer), and presence or absence of $70 \%$ shading; with two additional control treatments. Surveys on topsoil physical-chemical attributes and flora and soil coverage were conducted. Good correlation was observed between bulk density and total porosity. Vegetation comprised a total of 2,932 individuals of herbaceous, shrub and subshrub plants; 33 species in 11 families and 1 morphospecies were identified. A floristic survey of the tree stratum revealed 235 individuals belonging to 21 species and 14 families, as well as 2 unidentified species. The best natural regeneration index is observed in the $20-\mathrm{cm}$ topsoil layer, where shading exerts a positive influence on the humidity and natural regeneration of the seed bank. Topsoil from middle-stage forest is the most suitable for restoration of degraded pasture areas.
\end{abstract}

Index terms: ecosystem restoration, fertility, natural regeneration, topsoil application.

\section{Uso de topsoil na restauração de uma área de pastagem degradada}

Resumo - O objetivo deste trabalho foi avaliar a influência da espessura, sombreamento e origem do topsoil na restauração ambiental de uma área de pastagem degradada. O experimento foi realizado em delineamento em blocos casualizados, em esquema fatorial $(3 \times 2 \times 2)+2$. Os tratamentos foram compostos pela combinação das origens do topsoil (estágio inicial ou médio de regeneração), espessuras do topsoil (10, 20 ou $30 \mathrm{~cm}$ de camada superficial de solo) e ausência ou presença de sombrite de $70 \%$; com duas testemunhas adicionais (T1 e T2). Foi realizada a caracterização físico-química do topsoil, assim como o levantamento florístico e a cobertura do solo. Houve boa correlação entre a densidade do solo e a porosidade total. A cobertura vegetal desenvolvida apresentou um total de 2.932 indivíduos de hábitos herbáceo, arbustivos e subarbustivos, identificadas 33 espécies em 11 famílias e 1 morfoespécie. Já o levantamento florístico do estrato arbóreo registrou 235 indivíduos pertencentes a 21 espécies e 14 famílias e 2 espécies sem identificação. O topsoil de $20 \mathrm{~cm}$ de espessura é o que apresenta melhor índice de regeneração natural, onde o sombreamento exerceu uma influência positiva sobre a umidade e a regeneração natural do banco de sementes. O topsoil proveniente de floresta de estágio médio é o mais adequado para restauração de áreas de pastagem degradadas.

Termos para indexação: restauração de ecossistemas, fertilidade, regeneração natural, transposição de solo.

\section{Introduction}

In reclaiming soil and vegetation and recovering integrated biological processes, components of the soilplant-atmosphere system must be considered. Thus, revegetation should be dealt with by multidisciplinary teams, which identify problems and seek solutions based on the diverse aspects of scientific knowledge on soil (fertility, physical-chemical, biota, nutrient cycling); plants (botany, physiology, interactions with animals); atmosphere (weather); and their ecological interactions (Leal Filho et al., 2013).

The technique of topsoil application, which is both inexpensive and simple to perform, restores degraded land acting as a source of propagules for a great diversity of organisms, which allows a quick succession. Adding concentrated organic topsoil and nutrients to a degraded area under natural regeneration can contribute significantly to its resilience (Bechara et al., 2007). 
Thus, topsoil use can be a crucial tool for successful revegetation of degraded areas (Zhang et al., 2001). The high density and diversity values of the soil seed bank in most surveys in Brazilian forests reveal the potential of using the seed bank in restoring degraded areas, thereby increasing diversity and contributing to the maintenance of restoration projects.

Pasture areas in Brazil occupy approximately 172 million hectares, of which approximately $80 \%$ are degraded at some degree. These pastures are mainly composed of grasses of the Urochloa (Syn. Brachiaria) genus (Reaser et al., 2005), whose species tend to be invasive. For this reason, they are identified as an important obstacle to natural regeneration, forest succession, and development of native species (Pilon \& Duringan, 2013). Thus, topsoil application as a forest restoration technique in abandoned pasture has been widely used in recent years, as it is a lowcost and efficient technique in restoring structure, function, diversity and dynamics of degraded areas as compared to the reference ecosystem. Furthermore, topsoil is a nutrient-rich material for plant propagules and soil microorganisms in restoration projects (Golos \& Dixon, 2014).

However, an important feature of topsoil that must be better defined is its thickness, because the plant community depends largely on topsoil to develop properly in the environment. Ideally, topsoil is applied keeping its original thickness; but, in case of insufficient topsoil available, local losses may occur during operations.

The objective of this work was to evaluate the influence of topsoil thickness, shading and origin when performing environmental restoration in a degraded pasture area.

\section{Materials and Methods}

The experimental area, located in the Passa Sete farm, which belongs to a mining company (Anglo American Brazil) headquartered in the municipality of Conceição do Mato Dentro, in the state of Minas Gerais, Brazil (18 $\left.51^{\prime} 47.34^{\prime \prime} \mathrm{S}, 43^{\circ} 24^{\prime} 2.71^{\prime \prime} \mathrm{W}\right)$, occupies an area of $1,260 \mathrm{~m}^{2}$ of degraded pasture, formed predominantly by Urochloa sp. and occasionally by Sida sp.

Vegetation found in this environment is characterized by fragments of semideciduous forest in the early and middle stages of forest regeneration (Machado et al., 2010). The dominant climate in the region is Cwa (according to the Köppen classification), with a dry season lasting 4-5 months that coincides with the coldest months. The annual average temperature is $20.6^{\circ} \mathrm{C}$ and relative humidity ranges between 75 and $80 \%$. Average annual rainfall ranges between 1,400 and $1,500 \mathrm{~mm}$, with rainfall concentrated from November to March. Predominant soils in the region are Haplic Rhodic Ferralsols, Haplic Cambisols, and Dark Red Argisols, and occur in areas with a predominantly slightly hilly relief (FAO, 2006).

Topsoil used in this study was taken from two distinct areas of seasonal semideciduous montane forest, located within the limits of the tailings dam established by Anglo American Brazil. In the first area, the forest was in the middle regeneration stage, and the topsoil had been removed and stacked 6 months before the experiment began. In the second area, the forest was in the early regeneration stage, and topsoil was removed by the time the experiment started, in February 2012.

Fourteen treatments and three replicates were established and implemented in 42 plots of $5 \times 5 \mathrm{~m}$ $\left(25 \mathrm{~m}^{2}\right)$. The experiment was conducted in a randomized complete block design with a factorial $(3 \times 2 \times 2) 2$ layout. Treatments combined three aspects: topsoil thicknesses $(10,20$, or $30 \mathrm{~cm}$ superficial soil layer), topsoil origins (forest at early or middle regeneration stage) and presence or absence of $70 \%$ shading. Two additional control treatments marked only by the presence or absence of shading were also performed. Treatments were identified by the following codes: $0-\mathrm{C}$ and $0-\mathrm{S}$ (control treatments, with and without shading, respectively); 10M-C and 10M-S (10-cm-thick topsoil from middle-stage forest, with and without shading; 10I-C and 10I-S (10-cm-thick topsoil from early-stage forest, with and without shading; 20M-C and 20M-S (20-cm-thick topsoil from middle-stage forest, with and without shading; 20I-C and 20I-S (20-cm-thick topsoil from early-stage forest, with and without shading; 30M-C and 30M-S (30-cm-thick topsoil from middle-stage forest, with and without shading; 30I-C and 30I-S (30-cm-thick topsoil from early-stage forest, with and without shading. The plots were assembled and separated from each other by wooden rods to contain the movement of topsoil between plots. Each block was divided into two rows of seven plots; between

Pesq. agropec. bras., Brasília, v.52, n.11, p.1080-1090, nov. 2017 DOI: 10.1590/S0100-204X2017001100014 
the rows, 1-m-wide access roads were established and between blocks of $1.5 \mathrm{~m}$.

Topsoil was trucked to the experimental area and deposited in the plots with the help of backhoes and/ or wheelbarrows, and it was then spread with hoes according to the randomly selected treatment for each plot. In total, $180 \mathrm{~m}^{3}$ of topsoil was used.

Samples were collected in June, 2012 for the soil physical-chemical characterization. From each plot, five single $0-10-\mathrm{cm}$-thick samples were combined to form a composite sample, totaling 42 samples. Each sample was air-dried, passed through a 2-mm-mesh sieve, wrapped in plastic, labelled and sent to Soil Fertility Laboratory, at Universidade Federal dos Vales do Jequitinhonha e Mucuri (UFVJM).

Chemical analyses of soil samples followed the protocol of Claessen (1997) and were used to determine water $\mathrm{pH}$ level; $\mathrm{P}$ available, $\mathrm{K}$; $\mathrm{Ca}^{2+}, \mathrm{Mg}^{2+}$, $\mathrm{Al}^{3+}$; potential acidity ( $\left.\mathrm{H}+\mathrm{Al}\right)$; sum of bases $\left(\mathrm{Ca}^{2+}+\right.$ $\mathrm{Mg}^{2+}+\mathrm{K}^{+}$), cation exchange capacity at $\mathrm{pH} 7.0$ (CEC), effective cation exchange capacity, base saturation
$\left[\left(\mathrm{Ca}^{2+}+\mathrm{Mg}^{2+}+\mathrm{K}^{+}\right) / \mathrm{CEC}\right.$ at $\left.\mathrm{pH} 7\right], \mathrm{Al}$ saturation and soil organic matter content.

In November 2012, for the analyses of bulk density, particle density, and total porosity of topsoil using the volumetric ring method, 42 samples were collected from the center of each plot, with the help of volumetric rings. Each sample was also wrapped in plastic wrap, labelled and sent to Laboratório de Fertilidade do Solo at UFVJM for analysis.

To verify the structure of herbaceous components and estimate the percentage of live coverage on topsoil, the Braun-Blanquet scale (Braun-Blanquet, 1979) was used. In November 2012, five subplots of $1 \mathrm{x} 1 \mathrm{~m}\left(1 \mathrm{~m}^{2}\right)$ were randomly selected from each $25-\mathrm{m}^{2}$ plot, and all individuals present within each subplot were drawn, numbered, and identified. Soil coverage was visually estimated in each subplot selected, such that soil coverage in the subplots amounted to $20 \%$ of the total coverage of the plot.

Species identification was performed immediately in the field when possible. When it was not possible,

Table 1. Physical and chemical attributes of $0-10$-cm-thick topsoil applied in a degraded pasture area of Passa Sete farm, in the municipality of Conceição do Mato Dentro, in the state of Minas Gerais, Brazil ${ }^{(1)}$.

\begin{tabular}{|c|c|c|c|c|c|c|c|c|c|c|c|c|c|c|}
\hline \multirow{2}{*}{$\begin{array}{l}\text { Physical } \\
\text { attributes }\end{array}$} & \multicolumn{14}{|c|}{ Treatment } \\
\hline & $0-\mathrm{C}$ & $0-\mathrm{S}$ & $10 \mathrm{M}-\mathrm{C}$ & $10 \mathrm{M}-\mathrm{S}$ & $10 \mathrm{I}-\mathrm{C}$ & $10 \mathrm{I}-\mathrm{S}$ & $20 \mathrm{M}-\mathrm{C}$ & $20 \mathrm{M}-\mathrm{S}$ & $20 \mathrm{I}-\mathrm{C}$ & $20 \mathrm{I}-\mathrm{S}$ & $30 \mathrm{M}-\mathrm{C}$ & $30 \mathrm{M}-\mathrm{S}$ & $30 \mathrm{I}-\mathrm{C}$ & $30 I-S$ \\
\hline Sand $\left(\mathrm{g} \mathrm{kg}^{-1}\right)$ & 550 & 520 & 560 & 570 & 460 & 480 & 580 & 570 & 440 & 450 & 570 & 590 & 450 & 440 \\
\hline Silt $\left(\mathrm{g} \mathrm{kg}^{-1}\right)$ & 150 & 170 & 50 & 100 & 210 & 200 & 40 & 100 & 190 & 230 & 110 & 70 & 220 & 200 \\
\hline Clay $\left(\mathrm{g} \mathrm{kg}^{-1}\right)$ & 300 & 310 & 390 & 330 & 330 & 320 & 380 & 330 & 370 & 320 & 320 & 340 & 330 & 360 \\
\hline \multicolumn{15}{|l|}{ Chemical attributes } \\
\hline $\mathrm{pH} \mathrm{H}_{2} \mathrm{O}$ & $4.7 \mathrm{~b}$ & $5.2 \mathrm{a}$ & $4.7 b$ & $4.7 \mathrm{~b}$ & $4.7 \mathrm{~b}$ & $4.9 \mathrm{~b}$ & $4.6 \mathrm{~b}$ & $4.6 \mathrm{~b}$ & $4.6 \mathrm{c}$ & $4.8 \mathrm{~b}$ & $4.6 \mathrm{~b}$ & $4.7 b$ & $4.6 \mathrm{~b}$ & $4.7 \mathrm{~b}$ \\
\hline $\mathrm{P}\left(\mathrm{mg} \mathrm{dm} \mathrm{dm}^{-3}\right)$ & $0.5 \mathrm{c}$ & $0.6 \mathrm{~b}$ & $0.8 \mathrm{~b}$ & $1.0 \mathrm{a}$ & $0.9 \mathrm{~b}$ & $0.9 \mathrm{~b}$ & $0.8 \mathrm{~b}$ & $0.9 \mathrm{~b}$ & $0.9 \mathrm{~b}$ & $0.9 b$ & $0.8 \mathrm{~b}$ & $1.0 \mathrm{a}$ & $0.9 \mathrm{~b}$ & $0.8 \mathrm{~b}$ \\
\hline $\mathrm{K}^{+}\left(\mathrm{mg} \mathrm{dm}^{-3}\right)$ & $61.6 \mathrm{~d}$ & $74.4 \mathrm{c}$ & $106.4 \mathrm{c}$ & $139.0 \mathrm{a}$ & $109.1 \mathrm{c}$ & $126.5 \mathrm{a}$ & $132.0 \mathrm{a}$ & $140.5 \mathrm{a}$ & $107.3 \mathrm{c}$ & $117.5 \mathrm{~b}$ & $138.9 \mathrm{a}$ & $139.4 \mathrm{a}$ & $109.0 \mathrm{c}$ & $112.8 \mathrm{~b}$ \\
\hline $\mathrm{Ca}^{2+}\left(\mathrm{cmol}_{\mathrm{c}} \mathrm{dm}^{-3}\right)$ & $0.3 \mathrm{c}$ & $0.3 \mathrm{c}$ & $0.7 \mathrm{~b}$ & $1.0 \mathrm{a}$ & $0.5 \mathrm{c}$ & $0.5 \mathrm{c}$ & $1.0 \mathrm{a}$ & $1.0 \mathrm{a}$ & $0.5 \mathrm{c}$ & $0.4 \mathrm{c}$ & $0.8 \mathrm{~b}$ & $1.0 \mathrm{a}$ & $0.6 \mathrm{~b}$ & $0.4 \mathrm{c}$ \\
\hline $\mathrm{Mg}^{2+}\left(\mathrm{cmol}_{\mathrm{c}} \mathrm{dm}^{-3}\right)$ & $0.3 \mathrm{a}$ & $0.4 \mathrm{a}$ & $0.4 \mathrm{a}$ & $0.4 \mathrm{a}$ & $0.3 \mathrm{a}$ & $0.3 \mathrm{a}$ & $0.4 \mathrm{a}$ & $0.3 \mathrm{a}$ & $0.5 \mathrm{a}$ & $0.2 \mathrm{a}$ & $0.3 \mathrm{a}$ & $0.5 \mathrm{a}$ & $0.3 \mathrm{a}$ & $0.9 \mathrm{a}$ \\
\hline $\mathrm{Al}^{3+}\left(\mathrm{cmol}_{\mathrm{c}} \mathrm{dm}^{-3}\right)$ & $1.2 \mathrm{~d}$ & $1.1 \mathrm{~d}$ & $1.2 \mathrm{~d}$ & $1.2 \mathrm{~d}$ & $1.7 \mathrm{c}$ & $1.6 \mathrm{c}$ & $1.4 \mathrm{c}$ & $1.2 \mathrm{c}$ & $1.8 \mathrm{~b}$ & $1.7 \mathrm{~b}$ & $1.3 \mathrm{c}$ & $1.4 \mathrm{c}$ & $1.8 \mathrm{a}$ & $1.6 \mathrm{c}$ \\
\hline $\mathrm{H}+\mathrm{Al}\left(\mathrm{cmol}_{\mathrm{c}} \mathrm{dm}^{-3}\right)$ & $5.2 \mathrm{c}$ & $4.7 \mathrm{c}$ & $8.0 \mathrm{~b}$ & $9.1 \mathrm{a}$ & $8.5 b$ & $8.8 \mathrm{a}$ & $10.3 \mathrm{a}$ & $9.5 \mathrm{a}$ & $8.2 b$ & $8.2 b$ & $10.0 \mathrm{a}$ & $8.8 \mathrm{a}$ & $8.4 \mathrm{~b}$ & $8.3 b$ \\
\hline $\mathrm{SB}\left(\mathrm{cmol}_{\mathrm{c}} \mathrm{dm}^{-3}\right)$ & $0.6 \mathrm{~d}$ & $0.9 \mathrm{~d}$ & $1.4 \mathrm{c}$ & $1.8 \mathrm{a}$ & $1.0 \mathrm{c}$ & $1.2 \mathrm{c}$ & $1.7 \mathrm{~b}$ & $1.6 \mathrm{~b}$ & $1.3 \mathrm{c}$ & $0.9 \mathrm{~d}$ & $1.5 \mathrm{~b}$ & $1.8 \mathrm{a}$ & $1.2 \mathrm{c}$ & $1.0 \mathrm{c}$ \\
\hline $\mathrm{t}\left(\mathrm{cmol}_{\mathrm{c}} \mathrm{dm}^{-3}\right)$ & $1.8 \mathrm{c}$ & $1.9 \mathrm{c}$ & $2.6 \mathrm{~b}$ & $3.0 \mathrm{a}$ & $2.7 \mathrm{~b}$ & $2.8 \mathrm{~b}$ & $3.1 \mathrm{a}$ & $2.9 \mathrm{a}$ & $3.0 \mathrm{a}$ & $2.6 \mathrm{~b}$ & $2.8 \mathrm{~b}$ & $3.2 \mathrm{a}$ & $3.1 \mathrm{a}$ & $2.5 \mathrm{~b}$ \\
\hline $\operatorname{CEC}\left(\mathrm{cmol}_{\mathrm{c}} \mathrm{dm}^{-3}\right)$ & $5.9 \mathrm{c}$ & $5.6 \mathrm{c}$ & $9.4 \mathrm{~b}$ & $10.9 \mathrm{a}$ & $9.5 \mathrm{a}$ & $9.9 \mathrm{a}$ & $12.0 \mathrm{a}$ & $11.1 \mathrm{a}$ & $9.4 \mathrm{a}$ & $9.1 \mathrm{~b}$ & $11.5 \mathrm{a}$ & $10.6 \mathrm{a}$ & $9.7 \mathrm{a}$ & $9.2 b$ \\
\hline SOM (dag kg-1) & $0.5 \mathrm{~d}$ & $1.0 \mathrm{~d}$ & $2.1 \mathrm{~b}$ & $2.0 \mathrm{~b}$ & $1.4 \mathrm{c}$ & $2.4 \mathrm{a}$ & $2.5 \mathrm{a}$ & $2.0 \mathrm{~b}$ & $1.6 \mathrm{c}$ & $2.2 b$ & $2.4 \mathrm{a}$ & $2.4 \mathrm{a}$ & $2.1 \mathrm{~b}$ & $1.3 \mathrm{c}$ \\
\hline Al saturation (\%) & $65.3 \mathrm{a}$ & $57.0 \mathrm{~b}$ & $46.0 \mathrm{~b}$ & $41.0 \mathrm{c}$ & $61.3 \mathrm{a}$ & $58.3 \mathrm{~b}$ & $45.0 \mathrm{~b}$ & $43.3 \mathrm{c}$ & $58.3 \mathrm{~b}$ & $64.3 \mathrm{a}$ & $47.0 \mathrm{~b}$ & $42.3 c$ & $60.0 \mathrm{a}$ & $62.0 \mathrm{a}$ \\
\hline Base saturation (\%) & $10.7 \mathrm{a}$ & $15.0 \mathrm{a}$ & $15.3 \mathrm{a}$ & $16.0 \mathrm{a}$ & $11.3 \mathrm{a}$ & $11.7 \mathrm{a}$ & $15.0 \mathrm{a}$ & $14.7 \mathrm{a}$ & $13.7 \mathrm{a}$ & $10.3 \mathrm{a}$ & $13.3 \mathrm{a}$ & $17.3 \mathrm{a}$ & $13.0 \mathrm{a}$ & $10.7 \mathrm{a}$ \\
\hline
\end{tabular}

${ }^{(1)}$ Means followed by equal letters, in the row, do not differ significantly by Tukey's test, at 5\% probability. $\mathrm{pH}\left(\mathrm{H}_{2} \mathrm{O}\right)$ ratio 1:2.5 (soil:water); $\mathrm{P}$ and $\mathrm{K}$ : Mehlich-1; Ca, Mg and Al: $\mathrm{KCl} 1 \mathrm{~mol} \mathrm{~L}^{-1} ; \mathrm{H}+\mathrm{Al}$ : calcium acetate $0.5 \mathrm{~mol} \mathrm{~L}^{-1}$ at $\mathrm{pH}$ 7.0; SB: sum of bases; t: effective cation exchange capacity; T: CEC pH 7.0; SOM: soil organic matter content; $\mathrm{M}$ : Al saturation; BS: base saturation. Treatments - 0-C and 0-S: control treatments, with and without shading, respectively; 10M-C and 10M-S: 10-cm-thick topsoil from middle-stage forest, with and without shading, respectively; 10I-C and 10I-S:10-cm-thick topsoil from early-stage forest, with and without shading, respectively; 20M-C and 20M-S: 20-cm-thick topsoil from middle-stage forest, with and without shading, respectively; 20I-C and 20I-S: 20-cm-thick topsoil from early-stage forest, with and without shading, respectively; 30M-C and 30M-S: 30-cm-thick topsoil from middle-stage forest, with and without shading, respectively; 30I-C and 30I-S: 30-cm-thick topsoil from early-stage forest, with and without shading, respectively. 
species were identified with the help of literature and photographic records. Species and families were classified according to Angiosperm Phylogeny Group (APG III) (Bremer et al., 2009), and their spellings and nomenclatural synonyms were verified at Tropicos (2014) and The International Plant Names Index (IPNI, 2012).

Survey of tree species was conducted throughout the area of the $25-\mathrm{m}^{2}$ plots, and all individuals existing within each plot were counted and identified. Identification, classification and verification of spellings and nomenclatural synonyms were performed using the same methods described for herbaceous plants.

Phytosociological parameters considered in the analysis of community organization were as follows: frequency, density, absolute and relative abundance and Shannon diversity index (Mueller-Dombois \& Ellenberg, 1974). To confirm the regeneration rate of species, the formula proposed by Finol (1971) was used: $\mathrm{NR}=[(\mathrm{RD}+\mathrm{RF}) / 2]$, where NR is the percentage of natural regeneration, $\mathrm{RD}$ is the relative density of the species, and RF is the relative frequency.

The data were evaluated using analysis of variance; for results significant at 5\% by F-test, and Dunnett's test at $5 \%$ probability was used to compare the means of all treatments with each control treatment. Factorial analysis of variance without control treatments was performed only when the result was significant in the previous analysis and was followed by Tukey's test at a $5 \%$ probability. All statistical analyses were performed using the software Statistica, version 10.0 (Statsoft, Inc., Tulsa, Oklahoma, USA).

\section{Results and Discussion}

In particle size analysis, percentages of sand, silt and clay were identified, according to Santos et al. (2006). Topsoil was observed to have a medium texture, with clay content below 35\% (Table 1). Particle density results did not differ according to treatments $(p=0.289)$; however, bulk density and total porosity revealed overall significant differences depending on the evaluated thicknesses $(p=0.001, p=0.000$, respectively).

When comparing bulk density in all treatments with bulk density in each control treatment (0-C and 0-S), the only treatment that showed no difference was $10 \mathrm{M}-$ $\mathrm{C}$ (Table 2). Even with significant differences among treatments, the highest values for bulk density are are not limiting for root growth. Soil water infiltration was between 1.27 and $1.57 \mathrm{~g} \mathrm{~cm}^{-3}$ (Corsini \& Ferraudo, 1999).

For total porosity, different results were observed. Compared to $0-\mathrm{C}$, treatments that showed significant differences were 10M-S, 20M-C, 20I-C, and 20I- S. Compared to $0-\mathrm{S}, 10 \mathrm{M}-\mathrm{C}$, and $30 \mathrm{I}-\mathrm{S}$ treatments were the only ones that did not differ significantly. It was also observed that treatments with higher total porosity values presented lower bulk density values. This was also found by Beutler et al. (2004).

The highest values for bulk density were observed in $10 \mathrm{M}-\mathrm{C}$ and $10 \mathrm{I}-\mathrm{C}$ treatments. For total porosity, the highest values were observed for 20M-C and 20I-C treatments, with good correlation with bulk density values, because the thickness with higher thickness value showed the lowest bulk density.

In terms of soil density, value for 10-cm-thick topsoil $\left(0.9743 \mathrm{~g} \mathrm{~cm}^{-3}\right)$ was higher than those for 20-cm-thick

Table 2. Bulk density and total porosity of topsoil in a degraded pasture area of Passa Sete farm, in the municipality of Conceição do Mato Dentro, in the state of Minas Gerais, Brazil, for each treatment compared to control treatments.

\begin{tabular}{lccccc}
\hline \multirow{2}{*}{ Treatment $^{(1)}$} & \multicolumn{2}{c}{ Bulk density $\left(\mathrm{g} \mathrm{cm}^{-3}\right)$} & & \multicolumn{2}{c}{ Total porosity $\left(\mathrm{cm}^{3} \mathrm{~cm}^{-3}\right)$} \\
\cline { 2 - 3 } \cline { 5 - 6 } $0-\mathrm{C}$ & $0-\mathrm{C}$ & $0-\mathrm{S}$ & & $0-\mathrm{C}$ & $0-\mathrm{S}$ \\
\hline $0-\mathrm{S}$ & - & $1.157^{\mathrm{ns}}$ & & - & $0.505^{\mathrm{ns}}$ \\
$10 \mathrm{M}-\mathrm{C}$ & $1.151^{\mathrm{ns}}$ & - & & $0.448^{\mathrm{ns}}$ & - \\
$10 \mathrm{M}-\mathrm{S}$ & $1.014^{\mathrm{ns}}$ & $1.014^{\mathrm{ns}}$ & & $0.519^{\mathrm{ns}}$ & $0.519^{\mathrm{ns}}$ \\
$10 \mathrm{I}-\mathrm{C}$ & $0.874^{*}$ & $0.874^{*}$ & & $0.623^{*}$ & $0.623^{*}$ \\
$10 \mathrm{I}-\mathrm{S}$ & $0.934^{*}$ & $0.934^{*}$ & & $0.586^{\mathrm{ns}}$ & $0.586^{*}$ \\
$20 \mathrm{M}-\mathrm{C}$ & $0.910^{*}$ & $0.910^{*}$ & & $0.574^{\mathrm{ns}}$ & $0.574^{*}$ \\
$20 \mathrm{M}-\mathrm{S}$ & $0.844^{*}$ & $0.844^{*}$ & & $0.632^{*}$ & $0.632^{*}$ \\
$20 \mathrm{I}-\mathrm{C}$ & $0.919^{*}$ & $0.919^{*}$ & & $0.594^{\mathrm{ns}}$ & $0.594^{*}$ \\
$20 \mathrm{I}-\mathrm{S}$ & $0.808^{*}$ & $0.808^{*}$ & & $0.643^{*}$ & $0.643^{*}$ \\
$30 \mathrm{M}-\mathrm{C}$ & $0.882^{*}$ & $0.882^{*}$ & & $0.618^{*}$ & $0.618^{*}$ \\
$30 \mathrm{M}-\mathrm{S}$ & $0.902^{*}$ & $0.902^{*}$ & & $0.608^{\mathrm{ns}}$ & $0.608^{*}$ \\
$30 \mathrm{I}-\mathrm{C}$ & $0.882^{*}$ & $0.882^{*}$ & & $0.617^{\mathrm{ns}}$ & $0.617^{*}$ \\
$30 \mathrm{I}-\mathrm{S}$ & $0.883^{*}$ & $0.883^{*}$ & & $0.597^{\mathrm{ns}}$ & $0.597^{*}$ \\
\hline
\end{tabular}

${ }^{(1)}$ Treatments: $0-\mathrm{C}$ and $0-\mathrm{S}$, control treatments, with and without shading, respectively; 10M-C and $10 \mathrm{M}-\mathrm{S}, 10-\mathrm{cm}$-thick topsoil from middlestage forest, with and without shading, respectively; 10I-C and 10I-S, 10 -cm-thick topsoil from early-stage forest, with and without shading, respectively; 20M-C and 20M-S, 20-cm-thick topsoil from middlestage forest, with and without shading, respectively; 20I-C and 20I-S, 20-cm-thick topsoil from early-stage forest, with and without shading, respectively; $30 \mathrm{M}-\mathrm{C}$ and $30 \mathrm{M}-\mathrm{S}, 30-\mathrm{cm}$-thick topsoil from middlestage forest, with and without shading, respectively; 30I-C and 30I-S, 30 -cm-thick topsoil from early-stage forest, with and without shading, respectively. ${ }^{\text {ns }}$ Not significant. *Significant at $5 \%$ probability by Dunnett's test.

Pesq. agropec. bras., Brasília, v.52, n.11, p.1080-1090, nov. 2017 DOI: 10.1590/S0100-204X2017001100014 
and $30-\mathrm{cm}$-thick topsoil $\left(0.8258\right.$ and $0.8920 \mathrm{~g} \mathrm{~cm}^{-3}$, respectively). In terms of total porosity, the value for 20 -cm-thick topsoil was $0.6372 \mathrm{~cm}^{3}$, which was statistically higher than values for 10 -cm-thick and 30-cm-thick topsoil.

Soil coverage values ranged from 3 to 19\% (for 20I-C and 10I-S treatments, respectively). Although 10I-S treatment showed the highest percentage of soil coverage in relation to species richess, only 11 species (the third smallest number of species) were observed in soils under this treatment. Nevertheless, 10I-S comprised 440 individuals, the second largest number among total individuals in this study (Table 3).

The values observed are considered low compared to those found by Silva et al. (2012) in the evaluation of a gravel soil coverage after using topsoil in the dry and the rainy seasons, with 66 and $82 \%$ coverage, respectively. In the present study, however, it is noteworthy that topsoil was applied in February, when there was a strong summer in the region, which led to low regeneration and high mortality. As the survey was conducted in the second week of November (beginning of the rainy season), most of the individuals were in initial development and therefore generated a minimum soil coverage in the plots. Thus, expectations were that, with consecutive rains, there would be an increase in soil coverage, since herbaceous and subshrub species play an important role in soil protection against erosive processes and in incorporating organic matter into the soil, thus contributing to nutrient cycling (Martins et al., 2002).

In addition to low vegetation, soil coverage was characterized by the dominance of Sida glaziovii K. Schum, considered a ruderal species that colonizes mainly pasture areas, propagates by seeds (Constantin et al., 2007) and inhabits places of low environmental stress and high disturbance intensity. It is usually herbaceous, with a rapid development cycle, high aggressiveness and low competitive capacity (Chaves \& Silva, 2012).

Vegetation developed on topsoil with or without shading comprised a total of 2,932 herbaceous, shrub, and subshrub individuals (Table 3). They were identified as belonging to 33 species in 11 families and 1 morphospecies. Asteraceae was the family with the largest number of species (9), followed by Fabaceae (6), Convolvulaceae and Malvaceae (4), Solanaceae (3) and Poaceae (2); the other families were represented by only 1 species each. Regarding the numbers of individuals, the most common families were the Malvaceae (1,956), Poaceae (159) and Cyperaceae (149). Anemochoric species were more frequent (50\%) than autochoric (25\%) and zoochoric species (23\%). However, in terms of number of individuals, autochoric species $(70 \%)$ were more abundant than anemochoric (20\%) and zoochoric species (12\%). The distribution of herbaceous, shrub and subshrub individuals in the different dispersal syndromes varied depending on topsoil origin, either with or without shading. A significant difference was observed among dispersal guilds and topsoil origins (Table 4).

Topsoil from early-stage forest was observed to alter the proportions of autochoric and anemochoric individuals, and topsoil from middle-stage forest changed the proportions of zoochoric individuals. However, the presence of shading favored anemochoric individuals, thus increasing their numbers in comparison with the number of individuals in the absence of shading. These anemochoric species produce seeds and vegetative propagules with great potential for colonization and reproduction (Moravcová et al., 2015).

Floristic survey of the tree stratum revealed 235 individuals of 21 species and 14 families, as well as two unidentified species classified as morphospecies (Table 5). The family with the highest species diversity was Fabaceae (4), followed by Rutaceae, Solanaceae, Myrtaceae and Asteraceae (2 each). However, the family with the highest number of individuals was Siparunaceae, with 133 individuals of Siparuna guianensis Aubl., which is known in Brazil as holy sheet, is an understory and late succession species and is widely distributed; it had been found in high densities in several previous surveys in the region (Prado Júnior et al., 2010; Lopes et al., 2011). These are not long-lived trees, but their substantial ecological plasticity leads to a high colonization capacity and makes them important in the tree community (Prado Júnior et al., 2012). The abundance of $S$. guianensis was associated with topsoil origin, which carried local vegetal memory and was, therefore, a determining factor for regeneration. However, these results were also influenced by the presence of shading on the plots, which facilitated germination of secondary species (to the detriment of pioneer ones), because it recreates an 
Table 3. List of herbaceous, shrub, and subshrub species observed in treatments in the experimental area of Passa Sete farm, in the municipality of Conceição do Mato Dentro, in the state of Minas Gerais, Brazil ${ }^{(1)}$.

\begin{tabular}{|c|c|c|c|c|c|c|c|c|c|c|c|c|c|c|c|c|c|c|c|c|c|c|}
\hline \multirow[t]{3}{*}{ Family/species } & \multicolumn{11}{|c|}{ With shading } & \multicolumn{10}{|c|}{ Without shading } & \multirow[b]{3}{*}{$\begin{array}{r}\text { Total } \\
(\mathrm{A}+\mathrm{B})\end{array}$} \\
\hline & \multirow[b]{2}{*}{$\overline{\mathrm{DS}^{(2)}}$} & \multirow{2}{*}{$\frac{\mathrm{C}}{0-\mathrm{C}}$} & \multicolumn{4}{|c|}{ Middle stage } & \multicolumn{5}{|c|}{ Early stage } & \multirow{2}{*}{$\frac{\mathrm{C}}{0-\mathrm{S}}$} & \multicolumn{4}{|c|}{ Middle stage } & \multicolumn{5}{|c|}{ Early stage } & \\
\hline & & & $\begin{array}{l}10 \\
M-C\end{array}$ & $\begin{array}{c}20 \\
\mathrm{M}-\mathrm{C}\end{array}$ & $\begin{array}{l}30 \\
\mathrm{M}-\mathrm{C}\end{array}$ & $\begin{array}{c}\text { Total } \\
1\end{array}$ & $\begin{array}{l}10 \\
\mathrm{I}-\mathrm{C}\end{array}$ & $\begin{array}{l}20 \\
\mathrm{I}-\mathrm{C}\end{array}$ & $\begin{array}{l}30 \\
\mathrm{I}-\mathrm{C}\end{array}$ & $\begin{array}{c}\text { Total } \\
2\end{array}$ & $\begin{array}{c}\text { Total } \\
\text { A }\end{array}$ & & $\begin{array}{c}10 \\
\mathrm{M}-\mathrm{S}\end{array}$ & $\begin{array}{c}20 \\
\mathrm{M}-\mathrm{S}\end{array}$ & $\begin{array}{c}30 \\
\mathrm{M}-\mathrm{S}\end{array}$ & $\begin{array}{c}\text { Total } \\
1\end{array}$ & $\begin{array}{l}10 \\
\mathrm{I}-\mathrm{S}\end{array}$ & $\begin{array}{l}20 \\
\mathrm{I}-\mathrm{S}\end{array}$ & $\begin{array}{l}30 \\
\mathrm{I}-\mathrm{S}\end{array}$ & $\begin{array}{c}\text { Total } \\
2\end{array}$ & $\begin{array}{c}\text { Total } \\
\text { B }\end{array}$ & \\
\hline \multicolumn{23}{|l|}{ Amaranthaceae } \\
\hline Amaranthus viridis & Ane & 0 & 0 & 0 & 0 & 0 & 1 & 0 & 2 & 3 & 3 & 1 & 0 & 2 & 0 & 2 & 0 & 0 & 2 & 2 & 5 & 8 \\
\hline Asteraceae & & & & & & & & & & & & & & & & & & & & & & \\
\hline Ageratum conyzoides & Ane & 0 & 4 & 0 & 1 & 5 & 14 & 5 & 7 & 26 & 31 & 2 & 1 & 0 & 0 & 1 & 3 & 26 & 2 & 31 & 34 & 65 \\
\hline Acanthospermum hispidum DC. & Ane & 0 & 0 & 2 & 0 & 2 & 1 & 4 & 4 & 9 & 11 & 0 & 1 & 1 & 0 & 2 & 3 & 0 & 0 & 3 & 5 & 16 \\
\hline Melampodium paniculatum & Ane & 0 & 0 & 0 & 0 & 0 & 0 & 15 & 0 & 15 & 15 & 0 & 0 & 0 & 0 & 0 & 0 & 0 & 0 & 0 & 0 & 15 \\
\hline Tagetes minuta & Ane & 0 & 1 & 0 & 1 & 2 & 5 & 0 & 0 & 5 & 7 & 0 & 0 & 0 & 0 & 0 & 0 & 2 & 0 & 2 & 2 & 9 \\
\hline Conyza bonariensis & Ane & 0 & 0 & 0 & 0 & 0 & 0 & 1 & 0 & 1 & 1 & 0 & 3 & 0 & 0 & 3 & 0 & 0 & 0 & 0 & 3 & 4 \\
\hline Ageratum fastigiatum & Ane & 0 & 0 & 0 & 0 & 0 & 0 & 0 & 0 & 0 & 0 & 0 & 3 & 0 & 0 & 3 & 0 & 0 & 0 & 0 & 3 & 3 \\
\hline Emilia fosbergii & Ane & 0 & 0 & 0 & 0 & 0 & 0 & 1 & 0 & 1 & 1 & 0 & 1 & 0 & 0 & 1 & 0 & 0 & 0 & 0 & 1 & 2 \\
\hline Gnaphalium coarctatum & Ane & 0 & 0 & 1 & 0 & 1 & 0 & 0 & 0 & 0 & 1 & 0 & 1 & 0 & 0 & 1 & 0 & 0 & 0 & 0 & 1 & 2 \\
\hline Siegesbeckia orientalis $L$. & Auto & 0 & 0 & 0 & 0 & 0 & 0 & 0 & 1 & 1 & 1 & 0 & 0 & 0 & 1 & 1 & 0 & 0 & 0 & 0 & 1 & 2 \\
\hline Commelinaceae & & & & & & & & & & & & & & & & & & & & & & \\
\hline Commelina benghalensis & Auto & 0 & 2 & 4 & 0 & 6 & 42 & 23 & 36 & 101 & 107 & 5 & 0 & 0 & 1 & 1 & 16 & 3 & 8 & 27 & 33 & 140 \\
\hline Convolvulaceae & & & & & & & & & & & & & & & & & & & & & & \\
\hline Merremia cissoides (Lam.) Hallier f. & Ane & 0 & 0 & 0 & 0 & 0 & 0 & 0 & 0 & 0 & 0 & 0 & 2 & 0 & 3 & 5 & 0 & 0 & 0 & 0 & 5 & 5 \\
\hline Dichondra microcalyx & Ane & 0 & 0 & 0 & 0 & 0 & 0 & 0 & 0 & 0 & 0 & 0 & 0 & 1 & 0 & 1 & 0 & 0 & 0 & 0 & 1 & 1 \\
\hline Ipomoea purpurea & Ane & 0 & 0 & 0 & 0 & 0 & 0 & 0 & 0 & 0 & 0 & 0 & 0 & 1 & 0 & 1 & 0 & 0 & 0 & 0 & 1 & 1 \\
\hline Ipomoea triloba & Ane & 0 & 0 & 0 & 0 & 0 & 0 & 0 & 0 & 0 & 0 & 0 & 1 & 0 & 0 & 1 & 0 & 0 & 0 & 0 & 1 & 1 \\
\hline Cyperaceae & & & & & & & & & & & & & & & & & & & & & & \\
\hline Cyperus esculentus $L$. & Ane & 0 & 0 & 2 & 0 & 2 & 13 & 35 & 65 & 113 & 115 & 0 & 1 & 2 & 2 & 5 & 3 & 8 & 18 & 29 & 34 & 149 \\
\hline Fabaceae & & & & & & & & & & & & & & & & & & & & & & \\
\hline Zornia reticulata & Zoo & 0 & 1 & 3 & 0 & 4 & 9 & 11 & 27 & 47 & 51 & 1 & 11 & 0 & 22 & 33 & 4 & 5 & 2 & 11 & 45 & 96 \\
\hline Desmodium barbatum & Zoo & 0 & 3 & 0 & 4 & 7 & 2 & 1 & 5 & 8 & 15 & 0 & 2 & 3 & 0 & 5 & 0 & 2 & 0 & 2 & 7 & 22 \\
\hline Aeschynomene denticulata & Auto & 0 & 0 & 2 & 0 & 2 & 1 & 3 & 0 & 4 & 6 & 0 & 0 & 0 & 0 & 0 & 0 & 0 & 0 & 0 & 0 & 6 \\
\hline Chamaecrista rotundifolia & Auto & 0 & 0 & 0 & 0 & 0 & 0 & 0 & 3 & 3 & 3 & 0 & 0 & 1 & 0 & 1 & 1 & 0 & 0 & 1 & 2 & 5 \\
\hline Crotalaria incana $L$. & Auto & 0 & 0 & 0 & 1 & 1 & 0 & 0 & 0 & 0 & 1 & 0 & 0 & 0 & 0 & 0 & 0 & 0 & 0 & 0 & 0 & 1 \\
\hline Stylosanthes viscosa & Auto & 0 & 0 & 0 & 0 & 0 & 0 & 0 & 0 & 0 & 0 & 0 & 0 & 0 & 0 & 0 & 0 & 1 & 0 & 1 & 1 & 1 \\
\hline Lamiaceae & & & & & & & & & & & & & & & & & & & & & & \\
\hline $\begin{array}{l}\text { Marsypianthes chamaedrys (Vahl) } \\
\text { Kuntze }\end{array}$ & Auto & 0 & 0 & 0 & 0 & 0 & 14 & 3 & 15 & 32 & 32 & 2 & 0 & 0 & 0 & 0 & 0 & 0 & 0 & 0 & 2 & 34 \\
\hline Malvaceae & & & & & & & & & & & & & & & & & & & & & & \\
\hline Sida glasiovii & Auto & 150 & 6 & 17 & 6 & 29 & 138 & 151 & 100 & 389 & 568 & 258 & 53 & 16 & 4 & 73 & 368 & 553 & 25 & 946 & 1,277 & 1,845 \\
\hline Sida rhombifolia & Zoo & 0 & 1 & 2 & 0 & 3 & 1 & 3 & 11 & 15 & 18 & 3 & 4 & 10 & 2 & 16 & 2 & 0 & 25 & 27 & 46 & 64 \\
\hline Sidastrum micranthum & Auto & 0 & 7 & 7 & 0 & 14 & 3 & 2 & 1 & 6 & 20 & 1 & 3 & 3 & 2 & 8 & 0 & 0 & 1 & 1 & 10 & 30 \\
\hline Sida cordifolia & Zoo & 0 & 1 & 0 & 1 & 2 & 1 & 2 & 0 & 3 & 5 & 3 & 1 & 0 & 5 & 6 & 1 & 2 & 0 & 3 & 12 & 17 \\
\hline Unidentified & & & & & & & & & & & & & & & & & & & & & & \\
\hline Morphospecies 1 & Ane & 0 & 9 & 20 & 6 & 35 & 6 & 9 & 7 & 22 & 57 & 0 & 20 & 7 & 6 & 33 & 21 & 12 & 12 & 45 & 78 & 135 \\
\hline Poaceae & & & & & & & & & & & & & & & & & & & & & & \\
\hline $\begin{array}{l}\text { Brachiaria decumbens (Stapf) R.D. } \\
\text { Webster }\end{array}$ & Ane & 0 & 1 & 0 & 0 & 1 & 12 & 16 & 30 & 58 & 59 & 11 & 7 & 4 & 2 & 13 & 4 & 11 & 10 & 25 & 49 & 108 \\
\hline Melinis minutiflora P. Beauv. & Ane & 0 & 0 & 0 & 0 & 0 & 6 & 0 & 17 & 23 & 23 & 0 & 0 & 1 & 0 & 1 & 17 & 10 & 0 & 27 & 28 & 51 \\
\hline Rubiaceae & & & & & & & & & & & & & & & & & & & & & & \\
\hline Diodia teres Walt. & Zoo & 0 & 0 & 0 & 0 & 0 & 0 & 12 & 0 & 12 & 12 & 0 & 0 & 2 & 44 & 46 & 0 & 0 & 3 & 3 & 49 & 61 \\
\hline Solanaceae & & & & & & & & & & & & & & & & & & & & & & \\
\hline Physalis angulata & Zoo & 0 & 0 & 1 & 0 & 1 & 0 & 3 & 1 & 4 & 5 & 0 & 1 & 0 & 0 & 1 & 3 & 9 & 0 & 12 & 13 & 18 \\
\hline Datura stramonium L. & Zoo & 0 & 2 & 2 & 0 & 4 & 0 & 0 & 1 & 1 & 5 & 0 & 1 & 1 & 2 & 4 & 0 & 3 & 2 & 5 & 9 & 14 \\
\hline Solanum viarum & Zoo & 0 & 0 & 0 & 0 & 0 & 0 & 0 & 0 & 0 & 0 & 0 & 0 & 0 & 0 & 0 & 0 & 0 & 1 & 1 & 1 & 1 \\
\hline Total individuals & & 150 & 33 & 61 & 18 & 121 & 248 & 274 & 320 & 902 & 1,173 & 284 & 108 & 52 & 96 & 268 & 440 & 619 & 107 & 1,166 & 1,718 & 2,932 \\
\hline Total species & & 1 & 10 & 11 & 5 & 18 & 13 & 14 & 15 & 25 & 27 & 8 & 14 & 13 & 13 & 27 & 11 & 12 & 11 & 21 & 31 & 37 \\
\hline
\end{tabular}


shade-tolerant understory microclimate to which these species are adapted (Valentini et al., 2010).

Regarding species diversity, 20M-C contained the largest number of species (14), followed by 30M-C (11) and 10M-C (7) (Table 6). The Shannon index was 1.91, a considerable value in terms of diversity. Comparing the rates of species and individuals belonging to the three ecological groups (pioneers, initial secondary, late secondary and without characterization), it was observed that $53 \%$ of species were pioneers. However, $69 \%$ of individuals were late secondary species. Differences among guilds and topsoil origins were found only for initial secondary, autochoric dispersion and middle-stage topsoil. Animals as dispersal agents

Table 4. Contingency table with observed and expected (in parentheses) frequencies of herbaceous, shrub, and subshrub individuals.

\begin{tabular}{|c|c|c|c|c|c|c|}
\hline \multirow[t]{2}{*}{ Dispersal syndrome } & \multicolumn{4}{|c|}{ Topsoil origin $(\%)^{(1)}$} & \multicolumn{2}{|c|}{ Chi-Square test } \\
\hline & FEI-SS & FEI-CS & FEM-SS & FEM-CS & $\chi^{2}$ & $\mathrm{p}$ \\
\hline Anemochoric & $164(270.7)$ & $276(202.8)$ & $73(60.3)$ & $48(27.2)$ & 82.862 & $0.000^{*}$ \\
\hline Autochoric & $976(795.3)$ & $536(595.8)$ & $84(177.0)$ & $52(79.9)$ & 56.156 & $0.000 *$ \\
\hline Zoochoric & $64(138.0)$ & $90(103.4)$ & $111(30.7)$ & $21(13.9)$ & 43.935 & $0.000^{*}$ \\
\hline$\chi^{2}$ & 263.87 & $1,607.23$ & 748.76 & $2,257.48$ & - & - \\
\hline $\mathrm{p}$ & $0.000 *$ & $0.000^{*}$ & $0.000 *$ & $0.000^{*}$ & - & - \\
\hline
\end{tabular}

${ }^{(1)}$ FEI-SS: forest in early stage, without shading; FEI-CS: forest in early stage, with shading; FEM-SS: forest in middle stage, without shading; FEMCS: forest in middle stage, with shading. *Significant at $5 \%$ probability by Dunnett's test.

Table 5. Phytosociological data for tree species observed in topsoil treatments in the experimental area of Passa Sete farm, in the municipality of Conceição do Mato Dentro, in the state of Minas Gerais, Brazil. ${ }^{(1)}$

\begin{tabular}{|c|c|c|c|c|c|c|c|}
\hline Species & $\mathrm{NI}$ & NP & $\mathrm{AF}(\%)$ & $\mathrm{AD}$ & $\mathrm{RF}(\%)$ & $\mathrm{RD}(\%)$ & NR $(\%)$ \\
\hline Siparuna guianensis & 133 & 18 & 42.86 & $1,266.67$ & 20.00 & 56.6 & 38.3 \\
\hline Zanthoxylum rhoifolium & 15 & 10 & 23.81 & 142.86 & 11.11 & 6.38 & 8.75 \\
\hline Solanum mauritianum & 12 & 9 & 21.43 & 114.29 & 10.00 & 5.11 & 7.55 \\
\hline Campomanesia xanthocarpa & 8 & 5 & 11.90 & 76.19 & 5.56 & 3.4 & 4.48 \\
\hline Myrcia splendens & 5 & 5 & 11.90 & 47.62 & 5.56 & 2.13 & 3.84 \\
\hline Cecropia hololeuca & 7 & 4 & 9.52 & 66.67 & 4.44 & 2.98 & 3.71 \\
\hline Solanum lycocarpum & 9 & 3 & 7.14 & 85.71 & 3.33 & 3.83 & 3.58 \\
\hline Xylopia sericea & 5 & 4 & 9.52 & 47.62 & 4.44 & 2.13 & 3.29 \\
\hline Casearia arborea & 5 & 4 & 9.52 & 47.62 & 4.44 & 2.13 & 3.29 \\
\hline Dictyoloma vandellianum & 5 & 4 & 9.52 & 47.62 & 4.44 & 2.13 & 3.29 \\
\hline Aegiphila sellowiana & 4 & 4 & 9.52 & 38.1 & 4.44 & 1.7 & 3.07 \\
\hline Plathymenia foliolosa & 3 & 3 & 7.14 & 28.57 & 3.33 & 1.28 & 2.3 \\
\hline Enterolobium contortisiliquum & 4 & 2 & 4.76 & 38.1 & 2.22 & 1.7 & 1.96 \\
\hline Eremanthus crotonoides & 3 & 2 & 4.76 & 28.57 & 2.22 & 1.28 & 1.75 \\
\hline Apuleia leiocarpa & 3 & 2 & 4.76 & 28.57 & 2.22 & 1.28 & 1.75 \\
\hline Piptadenia gonoacantha & 3 & 2 & 4.76 & 28.57 & 2.22 & 1.28 & 1.75 \\
\hline Matayba elaeagnoides & 2 & 2 & 4.76 & 19.05 & 2.22 & 0.85 & 1.54 \\
\hline Morphospecies 2 & 2 & 2 & 4.76 & 19.05 & 2.22 & 0.85 & 1.54 \\
\hline Morphospecies 1 & 3 & 1 & 2.38 & 28.57 & 1.11 & 1.28 & 1.19 \\
\hline Vernonia densiflora & 1 & 1 & 2.38 & 9.52 & 1.11 & 0.43 & 0.77 \\
\hline Sparattosperma leucanthum & 1 & 1 & 2.38 & 9.52 & 1.11 & 0.43 & 0.77 \\
\hline Trema micrantha & 1 & 1 & 2.38 & 9.52 & 1.11 & 0.43 & 0.77 \\
\hline Luehea grandiflora & 1 & 1 & 2.38 & 9.52 & 1.11 & 0.43 & 0.77 \\
\hline Total & 235 & 90 & 214.29 & $2,238.1$ & 100 & 100 & 100 \\
\hline
\end{tabular}

${ }^{(1)} \mathrm{NI}$, number of individuals; NP, number of plots; $\mathrm{AF}$, absolute frequency; $\mathrm{AD}$, absolute density (individuals per hectare); RF, relative frequency; RD, relative density; and $\mathrm{RN}$, regeneration index. 
Table 6. List of tree species observed in treatments in the experimental area of Passa Sete farm, in the municipality of Conceição do Mato Dentro, in the state of Minas Gerais, Brazil(1).

\begin{tabular}{|c|c|c|c|c|c|c|c|c|c|c|c|c|c|c|c|c|c|c|c|c|c|c|c|}
\hline \multirow[t]{3}{*}{ Family/Species } & \multirow[b]{3}{*}{ EG } & \multirow[b]{3}{*}{ DS } & \multicolumn{10}{|c|}{ With shading } & \multicolumn{10}{|c|}{ Without shading } & \multirow[b]{3}{*}{$\begin{array}{l}\text { Total } \\
(\mathrm{A}+\mathrm{B})\end{array}$} \\
\hline & & & \multirow{2}{*}{$\begin{array}{c}\mathrm{C} \\
0-\mathrm{C}\end{array}$} & \multicolumn{4}{|c|}{ Middle stage } & \multicolumn{5}{|c|}{ Early stage } & \multirow{2}{*}{$\begin{array}{c}\mathrm{C} \\
0-\mathrm{S}\end{array}$} & \multicolumn{4}{|c|}{ Middle stage } & \multicolumn{5}{|c|}{ Early stage } & \\
\hline & & & & $\begin{array}{c}10 \\
\mathrm{M}-\mathrm{C}\end{array}$ & $\begin{array}{c}20 \\
\mathrm{M}-\mathrm{C}\end{array}$ & $\begin{array}{c}30 \\
\mathrm{M}-\mathrm{C}\end{array}$ & $\begin{array}{c}\text { Total } \\
1\end{array}$ & $\begin{array}{l}10 \\
\mathrm{I}-\mathrm{C}\end{array}$ & $\begin{array}{l}20 \\
\mathrm{I}-\mathrm{C}\end{array}$ & $\begin{array}{l}30 \\
\mathrm{I}-\mathrm{C}\end{array}$ & $\begin{array}{c}\text { Total } \\
2\end{array}$ & $\begin{array}{c}\text { Total } \\
\text { A }\end{array}$ & & $\begin{array}{c}10 \\
M-S\end{array}$ & $\begin{array}{c}20 \\
\mathrm{M}-\mathrm{S}\end{array}$ & $\begin{array}{c}30 \\
\mathrm{M}-\mathrm{S}\end{array}$ & $\begin{array}{c}\text { Total } \\
1\end{array}$ & $\begin{array}{l}10 \\
\mathrm{I}-\mathrm{S}\end{array}$ & $\begin{array}{l}20 \\
\mathrm{I}-\mathrm{S}\end{array}$ & $\begin{array}{l}30 \\
\mathrm{I}-\mathrm{S}\end{array}$ & $\begin{array}{c}\text { Total } \\
2\end{array}$ & $\begin{array}{c}\text { Total } \\
\text { B }\end{array}$ & \\
\hline \multicolumn{24}{|l|}{ Annonaceae } \\
\hline Xylopia sericea A. St.-Hil. & $\mathrm{P}$ & Zoo & 0 & 1 & 2 & 1 & 4 & 0 & 0 & 0 & 0 & 4 & 0 & 0 & 0 & 0 & 0 & 0 & 0 & 1 & 1 & 1 & 5 \\
\hline \multicolumn{24}{|l|}{ Asteraceae } \\
\hline $\begin{array}{l}\text { Eremanthus crotonoides (DC.) } \\
\text { Sch. Bip. }\end{array}$ & $\mathrm{P}$ & Ane & 0 & 2 & 0 & 0 & 2 & 0 & 0 & 0 & 0 & 2 & 0 & 0 & 1 & 0 & 1 & 0 & 0 & 0 & 0 & 1 & 3 \\
\hline Vernonia densiflora Gardner & $P$ & Ane & 0 & 0 & 0 & 0 & 0 & 0 & 0 & 0 & 0 & 0 & 0 & 0 & 0 & 0 & 0 & 0 & 0 & 1 & 1 & 1 & 1 \\
\hline \multicolumn{24}{|l|}{ Bignoniaceae } \\
\hline $\begin{array}{l}\text { Sparattosperma leucanthum (Vell.) } \\
\text { K. Schum. }\end{array}$ & IS & Ane & 0 & 0 & 1 & 0 & 1 & 0 & 0 & 0 & 0 & 1 & 0 & 0 & 0 & 0 & 0 & 0 & 0 & 0 & 0 & 0 & 1 \\
\hline \multicolumn{24}{|l|}{ Cannabaceae } \\
\hline Trema micrantha (L.) Blume & $P$ & Zoo & 0 & 0 & 0 & 1 & 1 & 0 & 0 & 0 & 0 & 1 & 0 & 0 & 0 & 0 & 0 & 0 & 0 & 0 & 0 & 0 & 1 \\
\hline Fabaceae & & & & & & & & & & & & & & & & & & & & & & & \\
\hline $\begin{array}{l}\text { Enterolobium contortisiliquum } \\
\text { (Vell.) Morong }\end{array}$ & IS & Auto & 0 & 0 & 3 & 0 & 3 & 0 & 0 & 0 & 0 & 3 & 0 & 0 & 1 & 0 & 1 & 0 & 0 & 0 & 0 & 1 & 4 \\
\hline $\begin{array}{l}\text { Apuleia leiocarpa (Vogel) J.F. } \\
\text { Macbr. }\end{array}$ & IS & Ane & 0 & 1 & 2 & 0 & 3 & 0 & 0 & 0 & 0 & 3 & 0 & 0 & 0 & 0 & 0 & 0 & 0 & 0 & 0 & 0 & 3 \\
\hline $\begin{array}{l}\text { Piptadenia gonoacantha (Mart.) } \\
\text { J.F. Macbr. }\end{array}$ & $\mathrm{P}$ & Auto & 0 & 0 & 1 & 0 & 1 & 0 & 0 & 0 & 0 & 1 & 0 & 0 & 0 & 2 & 2 & 0 & 0 & 0 & 0 & 2 & 3 \\
\hline Plathymenia foliolosa Benth. & IS & Ane & 0 & 0 & 1 & 1 & 2 & 0 & 0 & 0 & 0 & 2 & 0 & 0 & 1 & 0 & 1 & 0 & 0 & 0 & 0 & 1 & 3 \\
\hline Morphospecies 2 & $\mathrm{WC}$ & Auto & 0 & 0 & 0 & 1 & 1 & 0 & 0 & 0 & 0 & 1 & 0 & 0 & 1 & 0 & 1 & 0 & 0 & 0 & 0 & 1 & 2 \\
\hline Lamiaceae & & & & & & & & & & & & & & & & & & & & & & & \\
\hline Aegiphila sellowiana Cham. & $\mathrm{P}$ & Zoo & 0 & 0 & 1 & 0 & 1 & 0 & 2 & 0 & 2 & 3 & 0 & 0 & 0 & 0 & 0 & 0 & 0 & 1 & 1 & 1 & 4 \\
\hline Malvaceae & & & & & & & & & & & & & & & & & & & & & & & \\
\hline Luehea grandiflora Mart. & $\mathrm{P}$ & Ane & 0 & 0 & 1 & 0 & 1 & 0 & 0 & 0 & 0 & 1 & 0 & 0 & 0 & 0 & 0 & 0 & 0 & 0 & 0 & 0 & 1 \\
\hline Myrtaceae & & & & & & & & & & & & & & & & & & & & & & & \\
\hline $\begin{array}{l}\text { Campomanesia xanthocarpa Mart. } \\
\text { ex O. Berg }\end{array}$ & LS & Zoo & 0 & 1 & 0 & 0 & 1 & 3 & 0 & 1 & 4 & 5 & 0 & 1 & 0 & 0 & 1 & 0 & 0 & 2 & 2 & 3 & 8 \\
\hline Myrcia splendens (Sw.) DC. & LS & Zoo & 0 & 1 & 0 & 0 & 1 & 0 & 2 & 1 & 3 & 4 & 0 & 0 & 0 & 0 & 0 & 0 & 0 & 1 & 1 & 1 & 5 \\
\hline Rubiaceae & & & & & & & & & & & & & & & & & & & & & & & \\
\hline Morphospecies 1 & WC & Zoo & 0 & 0 & 0 & 3 & 3 & 0 & 0 & 0 & 0 & 3 & 0 & 0 & 0 & 0 & 0 & 0 & 0 & 0 & 0 & 0 & 3 \\
\hline Rutaceae & & & & & & & & & & & & & & & & & & & & & & & \\
\hline Zanthoxylum rhoifolium Lam. & LS & Zoo & 0 & 0 & 2 & 4 & 6 & 1 & 0 & 1 & 2 & 8 & 0 & 0 & 1 & 2 & 3 & 1 & 0 & 3 & 4 & 7 & 15 \\
\hline $\begin{array}{l}\text { Dictyoloma vandellianum A.H.L. } \\
\text { Juss }\end{array}$ & $\mathrm{P}$ & Ane & 0 & 0 & 1 & 3 & 4 & 0 & 1 & 0 & 1 & 5 & 0 & 0 & 0 & 0 & 0 & 0 & 0 & 0 & 0 & 0 & 5 \\
\hline Salicaceae & & & & & & & & & & & & & & & & & & & & & & & \\
\hline Casearia arborea (Rich.) Urb. & IS & Zoo & 0 & 0 & 2 & 1 & 3 & 0 & 0 & 0 & 0 & 3 & 0 & 0 & 1 & 1 & 2 & 0 & 0 & 0 & 0 & 2 & 5 \\
\hline Sapindaceae & & & & & & & & & & & & & & & & & & & & & & & \\
\hline Matayba elaeagnoides Radlk. & IS & Zoo & 0 & 0 & 0 & 0 & 0 & 0 & 0 & 0 & 0 & 0 & 0 & 0 & 1 & 1 & 2 & 0 & 0 & 0 & 0 & 2 & 2 \\
\hline Siparunaceae & & & & & & & & & & & & & & & & & & & & & & & \\
\hline Siparuna guianensis Aubl. & LS & Zoo & 0 & 44 & 44 & 33 & 121 & 6 & 1 & 1 & 8 & 129 & 0 & 1 & 2 & 1 & 4 & 0 & 0 & 0 & 0 & 4 & 133 \\
\hline Solanaceae & & & & & & & & & & & & & & & & & & & & & & & \\
\hline Solanum mauritianum Scop. & $\mathrm{P}$ & Zoo & 0 & 2 & 4 & 1 & 7 & 0 & 0 & 0 & 0 & 7 & 0 & 2 & 0 & 1 & 3 & 0 & 2 & 0 & 2 & 5 & 12 \\
\hline Solanum lycocarpum A. St.-Hil. & $\mathrm{P}$ & Zoo & 1 & 0 & 0 & 0 & 0 & 0 & 1 & 0 & 1 & 2 & 7 & 0 & 0 & 0 & 0 & 0 & 0 & 0 & 0 & 7 & 9 \\
\hline Urticaceae & & & & & & & & & & & & & & & & & & & & & & & \\
\hline Cecropia hololeuca Miq. & $P$ & Zoo & 0 & 0 & 1 & 5 & 6 & 0 & 0 & 0 & 0 & 6 & 0 & 0 & 1 & 0 & 1 & 0 & 0 & 0 & 0 & 1 & 7 \\
\hline Total individuals & - & - & 1 & 52 & 66 & 54 & 172 & 10 & 7 & 4 & 21 & 194 & 7 & 4 & 10 & 8 & 22 & 1 & 2 & 9 & 12 & 41 & 235 \\
\hline Total species & & & 1 & 7 & 14 & 11 & 20 & 3 & 5 & 4 & 7 & 21 & 1 & 3 & 9 & 6 & 12 & 1 & 1 & 6 & 7 & 17 & 23 \\
\hline
\end{tabular}


offer a great advantage: they not only ensure the species' dissemination in the area, but also add other important species whose seeds are present in their faeces (Silva et al., 2012). Therefore, the rates found in this study for the number of species (57\%) and individuals (88\%) with zoochoric dispersion corroborate those reported by Silva et al. (2012), who observed zoochoric as the predominant dispersal syndrome among species (87.5\%).

Numbers of species and individuals observed in each treatment were different (Table 7). 20M-C and 30M-C treatments were the only ones to differ from both control treatments. Regarding the number of individuals, $10 \mathrm{M}-\mathrm{C}, 20 \mathrm{M}-\mathrm{C}$ and $30 \mathrm{M}-\mathrm{C}$ were the treatments that differed from both control treatments. Of the five species with the highest number of individuals and the best regeneration rates, four (Siparuna guianensis, Zanthoxylum rhoifolium, Campomanesia xanthocarpa and Myrcia splendens) were late shade-tolerant secondary species with occurrence in understory. This shows the positive effect of shading: an area that has

Table 7. Number of species and individual trees for each treatment in comparison with control treatments.

\begin{tabular}{lccccc}
\hline Treatment ${ }^{(1)}$ & \multicolumn{2}{c}{ Number of species } & & \multicolumn{2}{c}{ Number of individuals } \\
\cline { 2 - 3 } \cline { 5 - 6 } & $0-\mathrm{C}$ & $0-\mathrm{S}$ & & $0-\mathrm{C}$ & $0-\mathrm{S}$ \\
\hline $0-\mathrm{C}$ & - & $0.333^{\text {ns }}$ & & - & $0.333^{\text {ns }}$ \\
$0-\mathrm{S}$ & $0.333^{\text {ns }}$ & - & & $2.333^{\text {ns }}$ & - \\
$10 \mathrm{M}-\mathrm{C}$ & $3.000^{\text {ns }}$ & $3.000^{\text {ns }}$ & & $17.333^{*}$ & $17.333^{*}$ \\
$10 \mathrm{M}-\mathrm{S}$ & $1.333^{\text {ns }}$ & $1.333^{\text {ns }}$ & & $1.333^{\text {ns }}$ & $1.333^{\text {ns }}$ \\
$10 \mathrm{I}-\mathrm{C}$ & $1.667^{\text {ns }}$ & $1.667^{\text {ns }}$ & & $3.333^{\text {ns }}$ & $3.333^{\text {ns }}$ \\
$10 \mathrm{I}-\mathrm{S}$ & $0.333^{\text {ns }}$ & $0.333^{\text {ns }}$ & & $0.333^{\text {ns }}$ & $0.333^{\text {ns }}$ \\
$20 \mathrm{M}-\mathrm{C}$ & $6.333^{*}$ & $6.333^{*}$ & & $22.000^{*}$ & $22.000^{*}$ \\
$20 \mathrm{M}-\mathrm{S}$ & $3.333^{\text {ns }}$ & $3.333^{\text {ns }}$ & & $3.333^{\text {ns }}$ & $3.333^{\text {ns }}$ \\
$20 \mathrm{I}-\mathrm{C}$ & $2.333^{\text {ns }}$ & $2.333^{\text {ns }}$ & & $2.333^{\text {ns }}$ & $2.333^{\text {ns }}$ \\
$20 \mathrm{I}-\mathrm{S}$ & $0.000^{\text {ns }}$ & $0.000^{\text {ns }}$ & & $0.667^{\text {ns }}$ & $0.667^{\text {ns }}$ \\
$30 \mathrm{M}-\mathrm{C}$ & $5.333^{*}$ & $5.333^{*}$ & & $18.000^{*}$ & $18.000^{*}$ \\
$30 \mathrm{M}-\mathrm{S}$ & $2.000^{\text {ns }}$ & $2.000^{\text {ns }}$ & & $2.667^{\text {ns }}$ & $2.667^{\text {ns }}$ \\
$30 \mathrm{I}-\mathrm{C}$ & $1.333^{\text {ns }}$ & $1.333^{\text {ns }}$ & & $1.333^{\text {ns }}$ & $1.333^{\text {ns }}$ \\
$30 \mathrm{I}-\mathrm{S}$ & $2.000^{\text {ns }}$ & $2.000^{\text {ns }}$ & & $3.000^{\text {ns }}$ & $3.000^{\text {ns }}$ \\
\hline
\end{tabular}

(1)Treatments $-0-\mathrm{C}$ and $0-\mathrm{S}$ : control treatments, with and without shading, respectively; 10M-C and 10M-S: 10-cm-thick topsoil from middle-stage forest, with and without shading, respectively; 10I-C and 10I-S: $10-\mathrm{cm}$-thick topsoil from early-stage forest, with and without shading, respectively; 20M-C and 20M-S: 20-cm-thick topsoil from middle-stage forest, with and without shading, respectively; 20I-C and 20I-S: 20 -cm-thick topsoil from early-stage forest, with and without shading, respectively; 30M-C and 30M-I: $30-\mathrm{cm}$-thick topsoil from middle-stage forest, with and without shading, respectively; 30I-C and 30I-S: 30-cm-thick topsoil from early-stage forest, with and without

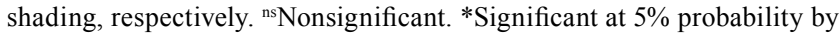
Dunnett's test. been recovering for only 9 months already presents a large number of species and individuals typical of advanced successional stages.

Approximately $91 \%$ of the identified species occurred in treatments with shading, and, of these, 95\% were observed in treatments with topsoil taken from middle-stage forest. Similarly, $86 \%$ of individuals occurred in treatments with shading, and $90 \%$ of which were observed in treatments with topsoil taken from middle-stage forest. This results confirm that, although shade-tolerant secondary species can develop and establish both in shaded areas (sub-forest) and clearings (Queiroz \& Firmino, 2014), their best performances are observed in shaded environments. This evidences the importance of creating small shading areas to enable the establishment of nonpioneer species in areas under restoration with the use of topsoil (Queiroz \& Firmino, 2014).

Comparisons with control treatments $(0-\mathrm{C}$ and $0-\mathrm{S}$, with and without shading respectively) showed that the determining factors for the success of treatments were topsoil origin and shading. Among the five species with the greatest number of individuals and better regeneration rates, only four (Siparuna guianensis, Zanthoxylum rhoifolium, Campomanesia xanthocarpa and Myrcia splendens) were late shade-tolerant secondary species occurring in the understory. This showed the positive effect of shading. Once an area is in recovery, after only nine months, it has a large number of species and individuals of advanced successional stages. Prado Júnior et al. (2010) observed that, out of the 20 species with higher importance value, 1 was classified as a pioneer species, 12 as early secondary species, and 7 as late secondary species. In the present study, analysis of the relative density per group showed the highest value for early successional species. However, analysis of the relative dominance showed higher values for late secondary species than for the others because generally such species are very long-lived and become large in forest formations.

\section{Conclusions}

1. The physical-chemical attributes of topsoil reach the best indices in the $0-10-\mathrm{cm}$ layer in degraded pastures. 
2. The best index of natural regeneration is presented in the thickness of $20 \mathrm{~cm}$, both in terms of species diversity and number of individuals.

3. Shading exerts a positive influence on the natural regeneration of the seed bank.

4. Topsoil origin is a factor that exerts a positive influence on physical-chemical attributes and floristic composition; topsoil from middle-stage forest is the most suitable for restoration of degraded pasture areas.

\section{Acknowledgments}

To Anglo American Brazil and Fundação de Amparo à Pesquisa do Estado de Minas Gerais (Fapemig), for financial and logistical support.

\section{References}

BECHARA, F.C.; CAMPOS FILHO, E.M.; BARRETO, K.D.; GABRIEL, V. de A.; ANTUNES, A.Z.; REIS, A. Unidades demonstrativas de restauração ecológica através de técnicas nucleadoras de biodiversidade. Revista Brasileira de Biociências, v.5, p.9-11, 2007. Suplemento 1.

BEUTLER, A.N.; CENTURION, J.F.; SILVA, A.P. da. Intervalo hídrico ótimo e a produção de soja e arroz em dois latossolos. Irriga, v.9, p.181-192, 2004.

BRAUN-BLANQUET, J. Fitosociologia: bases para el estudio de las comunidades vegetales. Rosario: H. Blume 1979. 820p.

BREMER, B.; BREMER, K.; CHASE, M.W.; FAY, M.F.; REVEAL, J.L.; SOLTIS, D.E; SOLTIS, P.S.; STEVENS, P.F. (Comp.). An update of the Angiosperm Phylogeny Group classification for the orders and families of flowering plants: APG III. Botanical Journal of the Linnean Society, v.161, p.105-121, 2009. DOI: $10.1111 /$ j.1095-8339.2009.00996.x.

CHAVES, E.; SILVA, L. H. S. Floristic survey of the herbaceousshrub layer of a gallery forest in Alto Paraíso de Goiás - GO, Brazil. Brazilian Archives of Biology and Technology, v.55, p.715-724, 2012. DOI: 10.1590/S1516-89132012000500011.

CLAESSEN, M.E.C. (Org.). Manual de métodos de análise de solo. 2.ed. rev. e atual. Rio de Janeiro: EMBRAPA-CNPS, 1997. 212p. (EMBRAPA-CNPS. Documentos, 1).

CONSTANTIN, J.; OLIVEIRA JÚNIOR, R.S. de; KAJIHARA, L.H.; ARANTES, J.G. Z. de; CAVALIERI, S.D. ALONSO, D.G. Controle de diferentes espécies de guanxuma com aplicações seqüenciais de flumiclorac-pentil. Acta Scientiarum. Agronomy, v.29, p.475-480, 2007. DOI: 10.4025/actasciagron.v29i4.403.

CORSINI, P.C.; FERRAUDO, A.S. Efeitos de sistemas de cultivo na densidade e macroporosidade do solo e no desenvolvimento radicular do milho em Latossolo Roxo. Pesquisa Agropecuária Brasileira, v.34, p.289-298, 1999. DOI: 10.1590/S0100204X1999000200017.
FAO. Food and Agriculture Organization of the United Nations. World reference base for soil resources 2006: a framework for international classification, correlation and communication. Rome: FAO, 2006. 145p. (World Soil Resources Reports, 103).

FINOL, U.H. Nuevos parámetros a considerarse en el analisis estructural de las sevas virgenes tropicales. Revista Forestal Venezolana, v.14, p.29-42, 1971.

GOLOS, P.J.; DIXON, K.W. Waterproofing topsoil stockpiles minimizes viability decline in the soil seed bank in an arid environment. Restoration Ecology, v.22, p.495-501, 2014. DOI: 10.1111/rec.12090.

IPNI. International Plant Names Index. The International Plant Names Index. 2012. Available at: <http:// www.ipni.org/index. html>. Accessed on: Sept. 182014.

LEAL FILHO, N.; SANTOS, G.R. dos; FERREIRA, R.L. Comparando técnicas de nucleação utilizadas na restauração de áreas degradadas na Amazônia brasileira. Revista Árvore, v.37, p.587-597, 2013. DOI: 10.1590/S0100-67622013000400002.

LOPES, S. de F.; SCHIAVINI, I.; PRADO JÚNIOR, J. A. do; GUSSON, A.E.; SOUZA NETO, A.R.; VALE, V.S. do.; DIAS NETO, O.C. Caracterização ecológica e distribuição diamétrica da vegetação arbórea em um remanescente de Floresta Estacional Semidecidual, na Fazenda Experimental do Glória, Uberlândia, MG. Bioscience Journal, v.27, p.322-335, 2011.

MACHADO, E.L.M.; GONZAGA, A.P.D.; CARVALHO, W.A.C.; SOUZA, J.S.; HIGUCHI, P.; SANTOS, R.M. dos; SILVA, A.C. da; OLIVEIRA-FILHO, A.T. de. Flutuações temporais nos padrões de distribuição diamétrica da comunidade arbóreo-arbustivo e de 15 populações em um fragmento florestal. Revista Árvore, v.34, p.723-732, 2010. DOI: 10.1590/S0100-67622010000400017.

MARTINS, S.V.; RIBEIRO, G.A.; SILVA JUNIOR, W.M. da; NAPPO, M.E. Regeneração pós-fogo em um fragmento de floresta estacional semidecidual no município de Viçosa, MG. Ciência Florestal, v.12, p.11-19, 2002. DOI: 10.5902/198050981696.

MORAVCOVÁ, L.; PYŠEK, P.; JAROŠIK, V.; PERGL, J. Getting the right traits: reproductive and dispersal characteristics predict the invasiveness of herbaceous plant species. PLoS One, v.10, e0123634, 2015. DOI: 10.1371/journal.pone.0123634.

MUELLER-DOMBOIS, D.; ELLENBERG, H. Aims and methods of vegetation ecology. New York: Wiley and Sons, 1974. 574p.

PILON, N.A.L.; DURIGAN, G. Critérios para indicação de espécies prioritárias para a restauração da vegetação de cerrado. Revista Scientia Forestalis, v.41, p.389-399, 2013.

PRADO JÚNIOR, J.A. do; LOPES, S. de F.; VALE, V.S. do; DIAS NETO, O.C.; SCHIAVINI, I. Comparação florística, estrutural e ecológica da vegetação arbórea das fitofisionomias de um remanescente urbano de cerrado. Bioscience Journal, v.28, p.456-471, 2012.

PRADO JÚNIOR, J.A. do; VALE, V.S. do; OLIVEIRA, A.P. de; GUSSON, A.E.; DIAS NETO, O.C.; LOPES, S. de F.; SCHIAVINI, I. Estrutura da comunidade arbórea em um fragmento de Floresta Estacional Semidecidual localizada na reserva legal da Fazenda

Pesq. agropec. bras., Brasília, v.52, n.11, p.1080-1090, nov. 2017 DOI: 10.1590/S0100-204X2017001100014 
Irara, Uberlândia, MG. Bioscience Journal, v.26, p.638-647, 2010 .

QUEIROZ, S.E.E.; FIRMINO, T. de O. Efeito de sombreamento na germinação e desenvolvimento de mudas de baru (Dipteryx alata Vog.). Revista Biosciências, v.20, p.72-77, 2014.

REASER, J.K.; GALINDO-LEAL, C.; ZILLER, S.R. Visitas indesejadas: a invasão de espécies exóticas. In: GALINDO-LEAL, C.; CÂMARA, I. de G. (Ed.). Mata Atlântica: biodiversidade, ameaças e perspectivas. São Paulo: Fundação SOS Mata Atlântica; Belo Horizonte: Conservação Internacional, 2005. p.392-405.

SANTOS, H.G. dos; JACOMINE, P.K.T; ANJOS, L.H.C. dos; OLIVEIRA, V.A. de; OLIVEIRA, J.B. de; COELHO, M.R.; LUMBRERAS, J. F.; CUNHA, T.J.F. (Ed.). Sistema brasileiro de classificação de solos. 2.ed. Rio de Janeiro: Embrapa Solos, 2006. 306p.
SILVA, R.K.S. da; FELICIANO, A.L.P.; MARANGON, L.C.; LIMA, R.B. de A.; SANTOS, W.B. dos. Estrutura e síndromes de dispersão de espécies arbóreas em um trecho de mata ciliar, Sirinhaém, Pernambuco, Brasil. Pesquisa Florestal Brasileira, v.32, p.1-11, 2012. DOI: 10.4336/2012.pfb.32.69.01.

TROPICOS. Missouri Botanical Garden. Available at: $<$ www. tropicos.org>. Accessed on: Sept. 152014.

VALENTINI, C.M.A.; RODRÍGUES-ORTÍZ, C.E., COELHO, M.F.B. Siparuna guianensis Aublet. (negramina): uma revisão. Revista Brasileira de Plantas Medicinais, v.12, p.96-104, 2010. DOI: $10.1590 /$ S1516-05722010000100014.

ZHANG, Z.Q.; SHU, W.S.; LAN, C.Y.; WONG, M.H. Soil seed bank as an input of seed source in revegetation of lead/zinc mine tailings. Restoration Ecology, v.9, p.378-385, 2001.

Received on February 1, 2016 and accepted on March 31, 2017 